\title{
ASSESSMENT OF KNOWLEDGE, ATTITUDES AND PRACTICES OF CONSUMERS REGARDING FOOD SAFETY IN BAHRI LOCALITY, KHARTOUM STATE, SUDAN
}

\author{
Layla Abdalkhalig. Aa ${ }^{1}$, Mohammed Babiker M. $\mathrm{H}^{2,3}{ }^{\square}$, I.E. Ola ${ }^{4}$, Mohammed Abdelsalam Abdalla ${ }^{5}$ \\ 1,4,5 Department of Preventive Veterinary Medicine and Public Health, Collage of Veterinary Medicine, Sudan \\ University of Science and Technology, Khartoum, Sudan. \\ ${ }^{2}$ Animal Resources Services Directorate, Ministry of Environment, Water and Agriculture (MEWA), 11195 P.0. \\ Box 7878 Riyadh, Kingdom of Saudi Arabia. \\ ${ }^{3}$ Department of Preventive Medicine and Public Health, College of Veterinary Medicine, University of Al \\ butana, Tamboul, P.O.Box 200 Rufaa, Sudan.
}

Received 3 September 2021

Accepted 17 September2021

Published 30 September2021

\section{CorrespondingAuthor}

Mohammed Babiker M. H, gatter943@gmail.com

DOI

10.29121/granthaalayah.v9.i9.2021. 4261

Funding: This research received no specific grant from any funding agency in the public, commercial, or not-for-profit sectors.

Copyright: (C) 2021 The Author(s). This is an open access article distributed under the terms of the Creative Commons Attribution License, which permits unrestricted use, distribution, and reproduction in any medium, provided the original author and source are credited.

\section{ABSTRACT}

Food borne illnesses are prevalent in all parts of the world. Contaminated food Contributes to 1.5 billion cases of diarrhea in children each year, resulting in more than three million premature deaths (WHO).

This study was conducted in August 2016 in Bahri locality, Khartoum state, to evaluate the knowledge, attitudes and practices of the consumers regard food safety.

A total of questionnaire guided face to face interview with 120 respondents were carried out. Major food safety knowledge concepts include clean and hygiene, general sanitation, safe storage of food, proper cooking of food, use of thermometer in cooking. In general, the respondents had good knowledge about some food safety related issues and not enough knowledge about other issues.

The results of the questionnaire showed that most of the respondents know the importance of washing hands before handling food $63 \%$ and wash the instruments and cleaning of the counter just after the preparation of the meal $83 \%$. The results of the questionnaire revealed that $50 \%$ of the respondents know the importance of covering hands with a bandage and gloves when preparing food with cuts on their hands. Also, its reveal that $80 \%$ of the respondents didn't know the proper way of thawing, and $84.2 \%$ of the respondents didn 't know food thermometer which use to ensuring proper cooking. This study recommend for Consumers should know and apply the five keys to safer food and implementing more training programs to the consumers to improve knowledge, attitudes and practices towards food safety.

Keywords: Bahri Locality, Food, Questionnaire, Knowledge, Respondents

\section{INTRODUCTION}

Food is basic human need and the major source of nutrients needed for human existence, so the consumers demand fresh, tasty, healthy and wholesome food products. Nevertheless, safety is in this framework considered an absolute requirement; placing unsafe food on the market is not an option in the consumer's mind Arie et al. (2010). Food choice is often influenced more by psychological interpretation of product properties than the physical properties of product themselves and food quality has been an important factor Rozin et al. (1986). Consumers often use their sense in their descriptions of safe food and feel that food that looks or smells bad should not eat. 
Consumers need to make informed choices about their food and how it is handled and prepared. Considerable amount of food preparation handling and storage take place in the domestic environment, especially at our homes, so by understanding the behaviors of the consumers and assuring the education of the consumers regarding the risk of unsafe food-handling practices is an essential element of the prevention of food -borne diseases Surjulal and Badrie (2004).

Food safety has emerged as an important global issue with international trade and public health implications. In less developed and developing countries, the food safety issues are increasing day by day due to various factors like the increase in the age of human populations, unplanned urbanization, migration and mass production of food due to population growth and changed food habits.

If the consumers are not taking healthy and safe food, then there will be probability of a greater number of cases of food borne diseases. When they will be ill, then these patients will invest to cure themselves. If the food which will be available to them is safe, then there will be fewer chances of food borne diseases.

People around the world become diseased from the food they consume. This illness is known as food-borne illness and is caused by harmful microorganisms and /or toxic chemicals WHO (2006).

Food borne illnesses occur due to eating contaminated food or drink. Large numbers of microbes and substances may contaminate foods. There are more than 250 known food borne illnesses, the most of them are infectious and are occur due to bacteria, viruses and parasites. Foodborne illness has more impact on health and economy in developing countries than in developed countries but answering data is not available, according to the World Health Organization the global incidence of illness is difficult to estimate, but it has been reported in 2005 alone 1.8 million persons died from diarrheal diseases. Contaminated food leads to 1.5 billion cases of diarrhea in children annually, resulting in more than three million premature deaths WHO (2010). Food borne illnesses have led to a significant morbidity and mortality all over the world.

Between all foods borne pathogens, the largest number of cases was reported for campylobacter and salmonella, 198,252 and 108,614, respectitely, largely relate to fresh poultry meat, poultry, eggs and pork [EFSA] (2011). It is best known that meat, as a rich nutrient media, offers a suitable ambient favorable for the spreading of microorganisms fouling meat and common food borne pathogens, in order to maintain meat safety and quality, enough maintenance technologies must be applied Aymerich et al. (2008).

Food safety is a supra primacy for authorities and spent all over the world. food safety objectives (FSO) and hazard analysis and critical control point (HACCP) systems are being submit all over the world. the European union (EU) is now fetching full-scale hygienic legislative bundle in addition to the established microbiological standards Commission Regulation (2005) into effect. It is sprightly food safety instructions commitment to when handling, dissolving, and stewing decays overcome.

In one deliberating food handlers were characterized as the major reason of food impureness Campos et al. (2009). Hand washing has been conceded as a necessary ingredient in the prevention of the diffusion of microbial contagiousness Fendler et al. (1998). If food handlers disregard the prominence of washing hand during food preparation, some bacteria like Escherichia-coli, staphylococcus aureus can be present on the hands of food handlers Lues and Tonder (2007). With the presence of these bacteria, the hands of food handlers can be played as carrier to disseminate noxious microorganisms through cross contamination Bas et al. (2006). 
Ehiri et al. (1996), pointed out that, knowledge himself is not adequate corroboration positive attitudes and safe behaviors between food handlers.as well as knowledge, attitudes are also a consequential factor that ensures lowering destination of food borne illness. Howes et al. (1996), indicate the engagement of positive behavior, attitudes and sustainable education of food handlers toward the fending of safe food handling practices.

The Objectives of current study were: to describe the demographic characteristic of the respondents, describe the knowledge of the respondents with regard to food safety and hygiene and to assess the knowledge, attitudes and practices of respondents toward meat regarding food safety and hygiene in Bahri locality.

\section{MATERIALS AND METHODS \\ 2.1. STUDY AREA (SEE THE MAP)}

This study was carried out in August 2016 at Bahri - locality, Khartoum state in order to evaluate food hygiene Knowledge, Attitudes, and Practices of consumers towards food safety. A total number of 120 respondents were selected randomly from different areas of Bahri -locality.

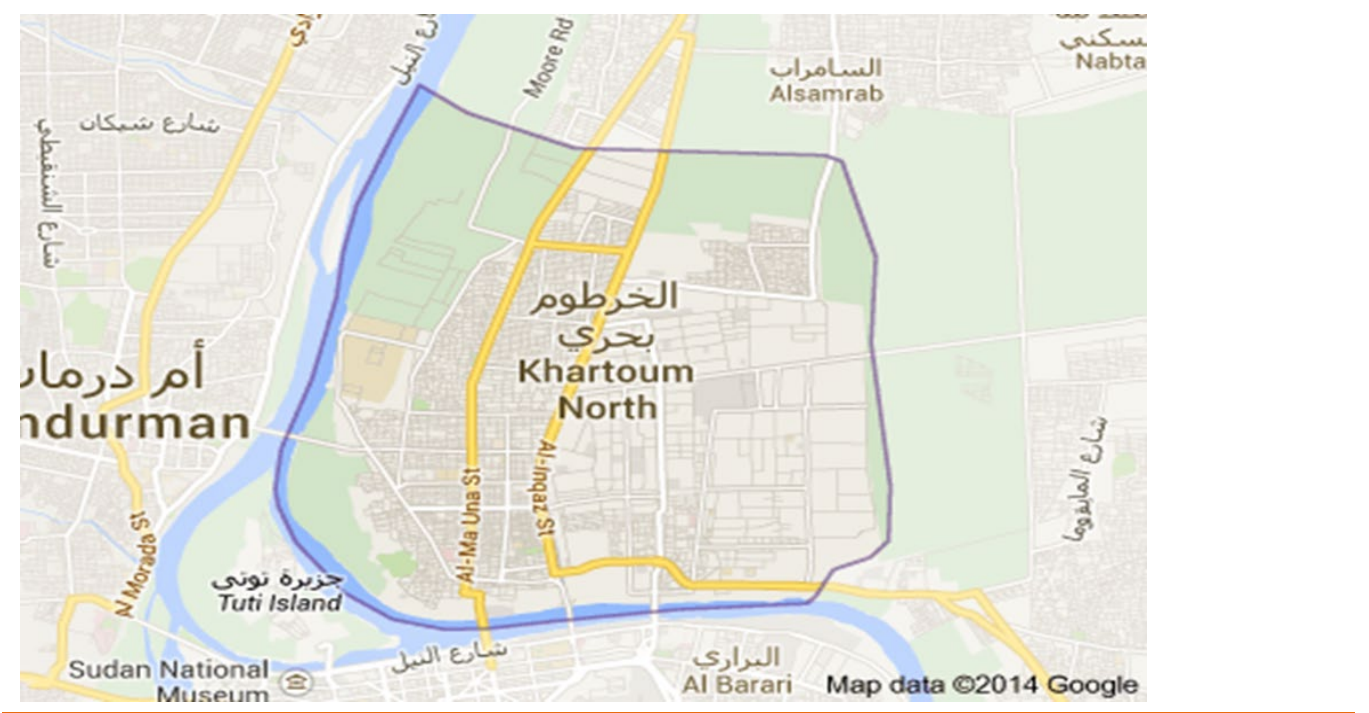

Figure 1 Bahri - locality, Khartoum north, Khartoum, Sudan

Bahri locality is a city in Khartoum state, located $11115.63333 \mathrm{~N}, 32.55 \mathrm{E}$ in the north of Khartoum city, the capital of Sudan. It is located on the north bank of the Blue Nile and the east bank of the River Nile, near the confluence of the Blue Nile with the White Nile and bridges connect it with both Khartoum to its south and Omdurman to its west.

\subsubsection{POPULATIONS}

It had a population of $1,012,211$ at the last Sudanese census in 2008. It is part of a three- city agglomeration (with Khartoum proper and Omdurman) with a combined population of 4,272,728 in 2008 . 


\subsubsection{ECONOMY AND INDUSTRY}

The industrial center of the region and the country, the neighborhood contains dockyards, marine and rail workshops, and sawmills. Khartoum North trades in cotton, grains, fruits, and livestock, industries include tanning, brewing, brickmaking, textile weaving, and food processing.

\subsection{METHODOLOGY}

\subsubsection{STUDY DESIGN}

The study designed as descriptive individual study using different independent variables.

\subsubsection{STUDY POPULATION}

The study covered 120 respondents randomly during the study period.

\subsection{SAMPLING, DATA COLLECTION AND STATISTICAL ANALYSIS}

Data was collected through questionnaire and face to face interviews with the respondents. A questionnaire has been developed to check the food safety knowledge, attitudes and practice.

The relationship among consumers concerns and knowledge on food safety will be determined by using a face-to-face conversation questionnaire (appendixes). Level of consumers knowledge about food safety selected according to Beck and Garden (2010) and by the concepts set by Byrd et al. (2007) and according to the five keys to safer food which are mentioned by WHO (2010).

A total of 120 consumers will be interviewed face to face in Bahri- locality. Questionnaire will be designed to obtain information's on food safety perception, and awareness of food- borne illnesses, contamination of food and hazards, food handling and safety practices at homes.

Exploratory data analysis will be done by using SPSS (statistical package for the social science) version 20 statistical software which included simple descriptive statistical analysis which displays the frequency distribution for all 4 tables that described in questionnaire.

Univariate analysis tables that used nonparametric chi-square test, describe the number of consumers, percentage, degree of freedoms and chi-square p-value $(<0.10)$ which explain if there is significant difference between knowledge on food safety and demographic characteristic of consumers, healthier life style, and the degree of responsibility of different entities regarding food safety.

\section{RESULTS}

Food safety begins at the earliest planning stages. The correct fit-out will assist in providing food premises that are easy to be cleaned and maintained and facilitate the production of safe food.

The present study reveals the knowledge, attitude and practices of consumers in Bahri locality. 


\subsection{DEMOGRAPHIC CHARACTERISTICS \\ 3.1.1. RESPONDENT'S GENDER, AGE AND EDUCATIONAL LEVELS}

In this study, a majority (87.5\%) of consumers were found to be females while the rest (12.5\%) were males (Table 1). $56.7 \%$ were found to be in age $20-40$ and the highest percentage of $41.7 \%$ for university education.

Table 1 Show the Gender, Age and Educational Levels of the 120 Consumers Targeted by This Study

\begin{tabular}{|ccc}
\hline Characteristics & Numbers & Percent (\%) \\
\hline Age (years) & & \\
\hline 20 & 7 & 5.8 \\
$20 \_40$ & 68 & 56.7 \\
$>40$ & 45 & 37.5 \\
Gender & & \\
Male & 15 & 12.5 \\
Female & 105 & 87.5 \\
\hline Education Level & & \\
Elementary & 27 & 22.5 \\
High school & 43 & 35.8 \\
University & 50 & 41.7
\end{tabular}

\subsubsection{PRACTICE TABLE}

Table 2 Shows Food Handling and Storage Before Preparation

\begin{tabular}{|c|c|c|c|c|}
\hline \multirow[t]{2}{*}{ Statement } & \multicolumn{4}{|c|}{ Response\% } \\
\hline & Always & Sometimes & Rarely & Never \\
\hline $\begin{array}{l}\text { I carefully check the purchase whether it is } \\
\text { damage or not }\end{array}$ & $\begin{array}{c}98 \\
(81.7)\end{array}$ & $8(6.7)$ & $5(4.2)$ & $9(7.5)$ \\
\hline $\begin{array}{l}\text { While purchasing frozen foods, I check whether } \\
\text { the product is really frozen or not }\end{array}$ & $\begin{array}{c}37 \\
(30.8)\end{array}$ & $19(15.8)$ & $26(21.7)$ & $\begin{array}{c}38 \\
(31.7)\end{array}$ \\
\hline $\begin{array}{l}\text { Are you careful about keeping raw meat or fish } \\
\text { away from ingredients that are eaten raw like } \\
\text { salad? }\end{array}$ & $\begin{array}{c}103 \\
(85.8)\end{array}$ & $6(5)$ & $5(4.2)$ & $6(5)$ \\
\hline Do you purchase food from an approved vender & $\begin{array}{c}13 \\
(10.8)\end{array}$ & $27(22.5)$ & $\begin{array}{c}26 \\
(21.7)\end{array}$ & $54(45)$ \\
\hline $\begin{array}{l}\text { Before any food is prepared, the safety of the food } \\
\text { is assessed by the food looks and smells }\end{array}$ & $\begin{array}{c}100 \\
(83.3)\end{array}$ & $6(5)$ & $3(2.5)$ & $11(9.2)$ \\
\hline $\begin{array}{l}\text { Store fresh produce in the refrigerator above raw } \\
\text { meat or poultry }\end{array}$ & $12(10)$ & $3(2.5)$ & $4(3.3)$ & $\begin{array}{c}101 \\
(84.2)\end{array}$ \\
\hline Expiration date & $\begin{array}{c}52 \\
(43.3)\end{array}$ & $59(49.2)$ & $4(3.3)$ & $5(4.2)$ \\
\hline
\end{tabular}

Table 2 shows most consumers (81.75) were found to always carefully check the purchase whether it is damage or not, while $4.2 \%$ were rarely carefully to check the purchase whether it is damage or not. The highest percentage of consumers $(31.7 \%)$ were never check whether the product is really frozen or not while $15.8 \%$ were sometimes check the purchase whether it is frozen or not. 
85.8\% of consumers were careful about keeping raw meat or fish away from ingredients that are eaten raw like salad, while $4.2 \%$ were rarely careful about keeping raw meat or fish away from ingredients that are eaten raw like salad.

$45 \%$ of the consumers were never purchase food from an approved vender, while $10.8 \%$ always do it. Most of the consumers $83.3 \%$ were found to assess the safety of the food before preparation by the food looks and smells, while $2.5 \%$ rarely assessed the safety of the food before preparation by the food looks and smells.

$84.2 \%$ were never store fresh product in the refrigerator above raw meat or poultry, while $2.5 \%$ were sometimes store fresh product in the refrigerator above raw meat or poultry. $49.2 \%$ were sometimes check the expiration date of the products, and 3.3\% were rarely check the expiration date of the product.

\begin{tabular}{|c|c|c|c|c|}
\hline \multirow[t]{2}{*}{ Statement } & \multicolumn{4}{|c|}{ Response\% } \\
\hline & Always & Sometimes & Rarely & Never \\
\hline Do you wash your hands before you handle food? & $\begin{array}{c}76 \\
(63.3)\end{array}$ & $13(10.8)$ & $18(15)$ & $\begin{array}{c}13 \\
(10.8)\end{array}$ \\
\hline Do you use hand sanitizer? & $8(6.7)$ & $8(6.7)$ & $13(10.8)$ & $88(73.3)$ \\
\hline $\begin{array}{l}\text { Are your food areas are cleaned with hot water } \\
\text { and soap? }\end{array}$ & $\begin{array}{c}25 \\
(20.8)\end{array}$ & $25(20.8)$ & $\begin{array}{c}33 \\
(27.5)\end{array}$ & $37(30.8)$ \\
\hline $\begin{array}{l}\text { Do you wash the utensils and clean the counter } \\
\text { just after the preparation of the meal? }\end{array}$ & $99(82.5)$ & $13(10.3)$ & $4(3.3)$ & $4(3.3)$ \\
\hline $\begin{array}{l}\text { To check the spoilage of the food in refrigerator } \\
\text { from 2-3 days ago, I taste them }\end{array}$ & $40(33.3)$ & $10(8.3)$ & $13(10.8)$ & $57(47.5)$ \\
\hline $\begin{array}{l}\text { Do you cover your hands with a bandage and } \\
\text { glove when you prepare food with cuts on your } \\
\text { hands? }\end{array}$ & $60(50)$ & $10(8.3)$ & $14(11.7)$ & $36(30)$ \\
\hline
\end{tabular}

Table 3 shows the highest percentage of the respondents $63.3 \%$ were found always wash their hands before they were handling food, same percentage of the consumers $10.8 \%$ were sometimes and never wash their hands before they were handling food. Most of the respondents $73.3 \%$ were never use hand sanitizer, $6.7 \%$ were sometimes and always use hand sanitizer.

$30.8 \%$ of the consumers were never clean food areas with hot water and soap, $20.8 \%$ of them were always and sometimes clean food areas with hot water and soap. $82.5 \%$ of the consumers were always wash the utensils and clean the counter just after the preparation of the meal, while 3.3\% of them were rarely and never wash the utensils and clean the counter just after the preparation of the meal.

$47.5 \%$ of the consumers were never check the spoilage of the food in refrigerator from 2-3 days ago by taste the food, while $8.3 \%$ were sometimes do it. $50 \%$ of the consumers were always cover their hands with a bandage and gloves when they prepare food with cuts on their hands, $8.3 \%$ were sometimes cover their hands with a bandage and gloves when they prepare food with cuts on their hands. 


\subsubsection{ATTITUDES TABLE}

\begin{tabular}{|c|c|c|c|}
\hline Statement & Agree & Disagree & No idea \\
\hline \multicolumn{4}{|l|}{ Left over: } \\
\hline Divided them into small portions put into refrigerator & $73(60.8)$ & $47(39.2)$ & 0 \\
\hline Put them into larger container & $50(41.7)$ & $70(58.3)$ & 0 \\
\hline You have no left problem & $39(32.5)$ & $81(67.5)$ & 0 \\
\hline \multicolumn{4}{|l|}{ Thawing: } \\
\hline In refrigerator conditions & $32(19.2)$ & $97(80.8)$ & 0 \\
\hline Put the frozen food in a nylon bag and immerse in hot water & $40(33.3)$ & $80(66.7)$ & 0 \\
\hline Put the frozen food just on the counter & $91(75.8)$ & $29(24.2)$ & 0 \\
\hline Keeping cooked meat at room temperature for $4-5$ hours & $76(63.3)$ & $43(35.8)$ & 0 \\
\hline $\begin{array}{l}\text { Raw and cooked foods should be stored separately to reduce } \\
\text { the risk of food contamination }\end{array}$ & $113(94.2)$ & $7(5.8)$ & 0 \\
\hline $\begin{array}{l}\text { Cooked meat can be left at room temperature over night to cool } \\
\text { before refrigerating }\end{array}$ & $61(50.80$ & $59(49.2)$ & 0 \\
\hline
\end{tabular}

\section{Left over}

$60.8 \%$ of the consumers were agree to divide left over into small portions and put into refrigerator while $39.2 \%$ were disagree, $41.7 \%$ agree to put them into larger container while $58.3 \%$ were disagree and $32.5 \%$ have no left-over problem while $67.5 \%$ have left over problem.

\section{Thawing}

$80.8 \%$ of the consumers were disagreeing of thawing in refrigerator conditions, while $19.2 \%$ agree of thawing in refrigerator conditions. $66.7 \%$ disagree to put the frozen food in nylon and immerse in hot water, while $33.3 \%$ agree to put the frozen food in nylon and immerse in hot water. 75.8\% agree to put the frozen food just on the counter, while $24.2 \%$ disagree to put the frozen food just on the counter.

$63.3 \%$ of the consumers agree to keep cooked meat at room temperature for 4-5 hours, and 35.8\% disagree to keeping cooked meat at room temperature for 45 hours. $94.2 \%$ agree to store raw and cooked foods separately to reduce the risk of food contamination, while $5.8 \%$ disagree to store raw and cooked foods separately to reduce the risk of food contamination.

$50.8 \%$ of the consumers agree to leave cooked meat at room temperature over night to cool before refrigerating, and $49.2 \%$ disagree to left cooked meat at room temperature over night to cool before refrigerating. 


\subsubsection{KNOWLEDGE TABLE}

\begin{tabular}{|c|c|c|c|}
\hline Statements & Correct & Incorrect & Don`t know \\
\hline Refrigerating food only slows bacterial growth & $58(48.3)$ & $13(10.8)$ & $45(37.5)$ \\
\hline Proper cooking includes meat cooked at $40^{\circ} \mathrm{C}$ & $18(15)$ & $16(13.3)$ & $86(71.7)$ \\
\hline $\begin{array}{l}\text { Cooked meat can be left at room temperature over night to cool before } \\
\text { refrigerating }\end{array}$ & $40(33.3)$ & $67(55.8)$ & $10(8.3)$ \\
\hline Meat thermometer are useful for ensuring food is cooked thoroughly & $13(10.8)$ & $5(4.2)$ & $101(84.2)$ \\
\hline $\begin{array}{l}\text { Well-cooked foods are free of contamination and don't cause risk to } \\
\text { consumers }\end{array}$ & $100(83.3)$ & $12(10)$ & $7(5.8)$ \\
\hline Freezing the food kills microorganisms in them & $30(25)$ & $11(9.2)$ & $74(61.7)$ \\
\hline Raw meat is a great risk for the consumer & $86(71.7)$ & $22(18.3)$ & $12(10)$ \\
\hline $\begin{array}{l}\text { Using same equipment for both raw and cooked foods no cause food safety } \\
\text { risks to consumers }\end{array}$ & $25(20.8)$ & $70(58.3)$ & $24(20)$ \\
\hline Raw food should be kept separately from cooked food & $108(90)$ & $8(6.7)$ & $4(3.3)$ \\
\hline Improper storage of food may be hazardous to health & $104(86.7)$ & $6(5)$ & $10(8.3)$ \\
\hline We should Consume low fat foods & $95(79.2)$ & $17(14.2)$ & $8(6.7)$ \\
\hline Limit my fresh vegetables and fruits consumption & $40(33.3)$ & $53(44.2)$ & $27(22.5)$ \\
\hline Limit my poultry meat consumption & $100(83.3)$ & $20(16,7)$ & 0 \\
\hline Limit my fish and fishery product & $109(90.8)$ & $11(9.2)$ & 0 \\
\hline Limit my egg consumption & $25(20,8)$ & $95(79,2)$ & 0 \\
\hline Limit my red meat consumption & $5(4,2)$ & $115(95,8)$ & 0 \\
\hline
\end{tabular}

The above Table 5 shows there were $48.3 \%$ out of 120 person answer correct, $10.8 \%$ answer incorrect and $37.5 \%$ answer they don't know that refrigerating food only slows bacterial growth.

$71.7 \%$ out of 120 -person don't know proper cooking includes meat cooked at $40^{\circ} \mathrm{c}$, while $15 \%$ answer correct proper coking includes meat cooked at $40^{\circ} \mathrm{c}$ and $13.3 \%$ answer incorrect proper cooking includes meats cooked at $40^{\circ} \mathrm{c}$.

Out of 120 person there is $55.8 \%$ answer incorrect cooked meat can be left at room temperature over night to cool before refrigerating, $33.3 \%$ answer correct cooked meat can be left at room temperature over night to cool before refrigerating and $8.3 \%$ don't know cooked meat can be left at room temperature over night to cool before refrigerating. $84.2 \%$ don't know meat thermometer are useful for ensuring food is cooked thoroughly, while $10.8 \%$ answer correct meat thermometer are useful for ensuring food is cooked thoroughly and $4.2 \%$ answer incorrect. Out of 120 person there is $83.3 \%$ answer correct well-cooked foods are free of contamination and don't cause risk to consumers, while $10 \%$ of them answer incorrect and 5.8\% answer they don't know well-cooked foods are free of contamination and don't cause risk to consumers.

$61.7 \%$ of the consumers answer they don't know freezing the food kills microorganisms in them, $25 \%$ answer correct freezing the food kills microorganisms in them and 9.2\% answer incorrect. Out of 120 person $71.7 \%$ answer correct raw meat is a great risk for the consumers, $18.3 \%$ answer incorrect and $10 \%$ answer don`t know raw meat is a great risk for the consumers. 
$58.3 \%$ of the consumers answer incorrect using same equipment for both raw and cooked food no cause food safety risks to consumers, and $20.8 \%$ answer correct, while $20 \%$ answer don `t know using same equipment for both raw and cooked food no cause food safety risks to consumers.

$90 \%$ out of 120 person answer correct raw food should be kept separately from cooked food, and 6.7\% answer incorrect, while 3.3\% answer don't know raw food should be kept separately from cooked food.

$86.7 \%$ out of 120 person answer correct improper storage of food may be hazardous to health, and $8.3 \%$ answer don`t know, and 5\% answer incorrect improper storage of food may be hazardous to health.

Out of 120 person there is $79.2 \%$ answer correct we should consume low fat foods, $14.2 \%$ answer incorrect, while $6.7 \%$ answer don't know we should consume low fat foods.

$44.2 \%$ of the consumers answer incorrect limit their fresh vegetables and fruits consumption, 33\% answer correct and $22.5 \%$ answer don't know limit their vegetables and fruits consumption. $83.3 \%$ out of 120 person answer correct limit their poultry meat consumption, while $16.7 \%$ answer incorrect limit their poultry meat consumption.

$90.8 \%$ of the consumers answer correct limit their fish and fishery products, while $9.2 \%$ answer incorrect limit their fish and fishery products.

79.25 out of 120 person answer incorrect limit their egg consumption and $20.8 \%$ answer correct. $95.8 \%$ of the consumers answer incorrect limit their red meat consumption while $4.2 \%$ of them answer correct limit their red meat consumption.

\section{DISCUSSION}

The aim of the present study was to examine knowledge, attitudes, and practices related to food safety among consumers, Bahri locality, Khartoum State, Sudan, August 2016. Socio-economic conditions of the respondents were also considered because of their vital importance for food hygiene practices.

During the research period, 120 respondents have been investigated randomly, to reveal the picture of the current situation.

Demographic characteristic revealed $56.7 \%$ of the respondents between 20-40 were $37,5 \%>40$ were, and 5,8 were $<20$ in age. $87,5 \%$ female and $12,5 \%$ male as shown in Table (4.1). As reflected by the study it was clear that, the educational level of the respondents was (22.5\%) elementary, (35.8\%) had high school, and 41,7 had university education. For better food hygiene a good educational level is required to enable the consumers to understand the concept of food hygiene.

The study revealed many critical features about the knowledge and practice of the respondents, almost $83.3 \%$ of the consumers have well knowledge and practice to assess the safety of the food before any food is prepared, by the food looks and smells. In agreement with the finding of Antoria (2002) that significant proportion of epidemiological diseases occurs due to unhygienic handling and poor food sanitation in restaurants, kitchens and other eating outlets, in the present study most of the respondents $73.3 \%$ were never use hand sanitizer.

In this study $63.3 \%$ of the respondents were always washing hands before starting food preparation and 50\% were always wearing gloves during food preparation and they sure these procedures reduce the risk of food contamination, these finding resemble the results of Ko (2011) and Rosnani et al. (2014). Ko (2011) found out that the broad majority of the restaurant's employees of Fu-Jen University 
in China believe that hands washing before touching food and wearing gloves for processing uncooked foods can reduce the risk of contamination. While Rosnani et al. (2014) pointed out to that touching food with bare hands is an awful practice with an average score of $78.9 \pm 25.611$ as thought by restaurant workers in Putrajaya, Malaysia.

The most important hygienic measure is cleaning of the working area. In this study $82.5 \%$ of the respondents were always wash the utensils and clean the counter just after the preparation of the meal and they sure that proper cleaning and handing of food preparation instruments decrease the hazard of food contamination. This was different from the observation of Ko (2011) who observed that only equal or less than four-point scales in respond to the following questions: when I washed the dishes, I would use the three-sink method, and if there were cracks on the dishes, I would still use them, and I did not need to clean the drainage every day.

In the present study $30 \%, 11.7 \%, 8.3 \%$ of the respondents were never, rarely and sometimes respectively, cover their hands with a bandage or gloves when preparing food with cuts on their hands.The finding of the present study did not confirm the finding of the previous epidemiological studies that shown E-coli, Salmonella species and Staphylococcus aureus can servive on the hand for a certain period of time in case the hands were not washed or even sometimes when washed, because of that wearing gloves during food preparation is accepts to noticeably decrease the food contamination Pether and Gilbert (1971), WHO (1989). In food handlers-associated food borne outbreaks, the most greatly reported way of transition involved poor hand hygiene or bare hand contact with food Todd et al. (2007). Azanza and Zamora -Luna (2005) found that the knowledge and applying of the basic principles of the hygiene like washing hands during preparation of food and serving, it has led to noticeably decreasing in the level of microbial contamination in Philippines. Van Kampen et al. (1998) found out that shortage of hand washers and the low level of the people's knowledge led to the preparation of unhealthy and hazard food in Jakarta.

In agreement with the finding WHO (2005), kinds of food that are mostly included in outbreaks of food borne diseases involve meat and meat product, milk and milk product, vegetables salads and puddings. In this study $85.8 \%$ of the respondents were found careful about keeping raw meat or fish away from ingredients that are eaten raw like salad, this result indicates most of the respondents have awareness about transmission of microorganisms from raw food like salad to cooked foods like meat or fish.

Rosnani et al. (2014) found out that $80.3 \%$ were not backing the proposing of storing raw and cooked food separately. Other common food-safety measures mentioned by Rosnani et al. (2014) included workers should not rub face or hands and hair and should not smoke during working and separate kitchen instruments that were used to serve and prepare cooked and raw foods. This finding of this study did confirm the findings of Ko (2011) who found that between the questions that had the highest outcome was, I think raw food and cooked food must be handled separately.The finding of the present study confirm the findings of the two previous studies Rosnani et al. (2014) and Ko (2011), 94.2\% of the respondent agreed that raw and cooked foods should be stored separately to reduce the risk of food contamination .

Incorrect thawing of frozen red meat, poultry and fish could lead to some food poisoning cases between the consumers Roberts (1982), WHO (1989) and Abdalla et al. (2008). This finding did confirm with the present study which found that, 
$33.3 \%$ of the respondents were agreed, put the frozen food in a nylon bag and immerse in hot water.

Salmonella is one of the major foodborne causes of gastroenteritis and often connected with contaminated poultry meat Bryan et al. (1995). Campylobacter also is one of the most common bacterial causes of acute gastroenteritis in humans in advanced countries Allos (2001). The finding of these studies did confirm the findings of the present study which found that $71.7 \%$ of the respondents agreed that raw meat is a great risk for the consumers.

Epidemiological studies often show the wrong handling of raw poultry products or consumption of under cooked poultry products as the most likely source of exposure to Campylobacter Kapperud et al. (2003),Kapperud et al. (1993) Luber et al. (2006). National-scale genotyping of Campylobacter species in Scotland was used to quantify the relative importance of various possible sources of human infection, most clinical isolates were due to chicken meat, identifying it as the main source of Campylobacter infection in humans Sheppard et al. (2009). The finding of these studies was confirming the finding of the present study, $83.3 \%$ of the respondents answer correct well-cooked foods are free of contamination and don't cause risk to consumers.

\section{CONCLUSION}

The study provided valuable information about evaluation of food hygiene knowledge, attitudes, and practices (KAP) of consumers in homes at Bahri locality. Major food safety knowledge concepts including clean and hygiene, prevention of cross contamination, general sanitation, and safe storage of food and correct thawing. The responses of interviewed consumers varied considerably, in general, the respondents had good knowledge about some food safety -related issues and not enough knowledge about other issues. The results of the questionnaire showed that the majority of the respondents know the importance of washing hands before handing food and cleaning the counter just after the preparation of the meal. The results of the questionnaire revealed that half (50\%) of the respondents know the importance of covering hands with a bandage and gloves when preparing food with cuts on their hands.

\section{RECOMMENDATIONS}

Implementing more training programs to the consumers to improve knowledge, attitudes and practices towards food safety, Consumers should know and apply the five keys to safer food. This study shows that there is a need for additional researches in the area of consumers and the possible risks they may pose

regarding food safety.

\section{REFERENCES}

Abdalla MA, Siham ES, Alian YYHA, Amel OB (2008). Microbial content of the domestic refrigerators in Khartoum area (Khartoum North). Sud. J. Vet. Sci. Anim. Husb. 47(1\&2): 15-23.

Allos, B.M. (2001). Campylobacter jejuni infections: Update on emerging issues and trends.Clin.Infect.Dis.32:1201-1206. Retrieved from https://doi.org/10.1086/319760

Arie, H., Havelaar; Brul, S.; Jong, R.; Marcel, H.; Beno, H.andkuile, T.(2010). Future challenges to Microbial Food Safety. International Journal of Food 


$\begin{array}{lllll}\text { Microbiology .Vol 139,Supplement,PpS79_S94. } & \text { Retrieved } & \text { from } \\ \text { https://doi.org/10.1016/j.ijfoodmicro.2009.10.015 } & & \end{array}$

Antoria, M.D.A., (2002). Brazil Institutional Experience for the Implementation of Risk Analysis on Food Safety. FAO/WHO Global forum of food safety regulations (Agenda item 4.49) G.F01/13.

Aymerich T, Picouet PA, Monfort JM. (2008). Decontamination technologies for meat products. meat sci 78: 114-29. Retrieved from https://doi.org/10.1016/j.meatsci.2007.07.007

Badrie, N.; Joseph, A and Chen, A. (2004). An observational study of food safety practices by street vendors and microbiological quality of street_purchased hamburger beef patties in Trinidad, West Indies. Internet Journal of Food Safety, Vol (3):25- 31. $\quad$ Retrieved from https://citeseerx.ist.psu.edu/viewdoc/download?doi=10.1.1.567.6522\&re $\mathrm{p}=\mathrm{rep} 1 \&$ type $=$ pdf

Bas, M., Ersun, A.S., \& Kivanc, G. (2006). The evaluation of food hygiene knowledge, attitudes, and practices of food handlers in food businesses in Turkey. food control, 17,317-322. $\quad$ Retrieved from https://doi.org/10.1016/j.foodcont.2004.11.006

Beck, P. and Garden-Robinson. J (2010). (book) Is Food in My Kitchen a Safety Hazard?.www.ag.ndsu.edu.

Bryan FL, Doyle (1995) MP. Health risks and consequences of Salmonella and Campylobacter jejuni in raw poultry.J Food protect ; 58:326-44. Retrieved from https://doi.org/10.4315/0362-028X-58.3.326

Byrd-Bredbenner, C.; Wheatly, V.; Schaffner, D.; Bruhn, C.; Blalock, L. and Maurer, J. (2007), "Development and implementation of a food safety knowledge instrument", Journal of Food Science Education, Vol. 6, pp. 46-55. Retrieved from https://doi.org/10.1111/j.1541-4329.2007.00029.x

Campos, A.K.C., Cardonha. A. M.S., Pinherio, L.B.G., Ferreira, N.R. Azevedo, P.R.M. (2009). Assessment of personal hygiene and practices of food handlers in municipal public schools of natal, Brazil. food control, 20, 807-810. Retrieved from https://doi.org/10.1016/j.foodcont.2008.10.010

Commission Regulation, (2005). Commission Regulation (EC) NO .2073 /2005 of 15 November 2005 on microbiological criteria for food stuffs (Text with EEA relevance). Official L338:1-26.

[EFSA] European food safety Authority. (2011). The European Union summary report on trends and sources of Zoonosis, Zoonotic agents and food-borne out breaks in 2009 .EFSA J 9:2090. Retrieved from https://doi.org/10.2903/j.efsa.2011.2090

Ehiri, J.E. and Morris, G.P. (1996). Hygiene training and education of food handlers. Journal of Ecology Food Nutrition 35: 243-251. Retrieved from https://doi.org/10.1080/03670244.1996.9991494

Fendler, E. J. Dolan.M.J, \&Williams, R.A. (1998). Hand washing and gloving for food protection, part1: Examination of the evidence-Diary, food and Environmental sanitation, 18, 81 -828.

Howes, M., McEwen, S., Griffiths, M. \& Harris, L., (1996). Food handler certification by home study: measuring changes in knowledge and behavior, Dairy food sanitation, VOL 16, pp, 737-44. Retrieved from https://agris.fao.org/agrissearch/search.do?recordID=US9718000 
Kapperud, G., E. Skjerve, L. Vik, K. Hauge, A. Lysaker, I. Aalmen, S.M. Ostroff, and M. Potter, (1993). Epidemiological investigation of risk factors for Campylobacter colonization in Norwegian broiler flocks. Epidemiological. Infect.111:245-255.

Retrieved

from https://doi.org/10.1017/S0950268800056958

Kapperud,G.,G.Espeland,E.Wahl,A.Walde,H.Herikstad,S.Gustavsen,I.Tveit,O.Natas,L. Bevanger,and A.Digranes, (2003). Factors associated with increased and decreased risk of campylobacter infection: A prospective case-control study in Norway. Am. J. Epidemiol.158:243-242. Retrieved from https://doi.org/10.1093/aje/kwg139

Ko W.H. (2011). Food Sanitation Knowledge, Attitude, Behavior for the University Restaurant Employees. Food and Nutrition Science. 2,744-750. Retrieved from https://doi.org/10.4236/fns.2011.27102

Luber, P., S. Brynestad, D. TOPSCH, k. Scherer, and E. Bartelt, (2006). Quantification of Campylobacter species cross-contamination during handling of contaminated fresh chicken parts in kitchens. Appl. Environ.Microbial.72:66-70. Retrieved from https://doi.org/10.1128/AEM.72.1.66-70.2006

Lues, J. F. R, \& Tonder, I. V, (2007). The occurrence of indicator bacteria on hands and aprons of food handler in the delicatessen sections of retail group. Food control, 18(4), 326-332. Retrieved from https://doi.org/10.1016/j.foodcont.2005.10.010

Pether JVS, Gilbert RJ (1971). The survival of Salmonellas on fingertip and transfer of the organisms to food, J. Hyg.69:673-681. Retrieved from https://doi.org/10.1017/S002217240002194X

Roberts, T. Buzby, J. and Lichtenberg, E (2003). Economic consequences of food borne hazards. In: food safety handbook. R.H. Schmidt and G. E. Rodrick (Eds), PP 89-124. John Wiley and Sons, inc., New jersey. Retrieved from https://doi.org/10.1002/047172159X.ch7

Roberts D. (1982). Bacteria of public health significance In Meat Microbiology. (Edited by Brown M.H.). Applied Science Publishers Ltd.319-386. Retrieved from https://doi.org/10.1007/978-94-011-9819-6_9

Rozin, P, Pelchat, M. L., and Fallon, A.E. (1986). Psycological factors influencing food choice. In R.C. Goften and McKenzie (Eds), PP.85-106. The food consumer. John Wiley and Sons Ltd, chichester and New York.

Rosnani A.H., R. Son, O. Mohhiddin, P. S.Toh and C. Chai (2014). Assessment of Knowledge, Attitudes and Practices Concerning Food Safety among Restaurant Workers in Putrajaya,Malaysia. Food Science and Quality Management, 32,20-28.

Sheppard, S.K., J.F.Dallas, N.J.Strachan, M.MacRae, N.D.McCarthy, D.J.Wilson, F.J.Gormley, D.Falush, I.D.Ogden, M.C.Maiden, and K.J.Forbes (2009). Campylobacter genotyping to determine the source of human infection.Clin.infect.Dis.48:1072-1078. Retrieved from https://doi.org/10.1086/597402

Surjulal, M.and Badrie, N. (2004). House hold consumer food safety study in Trinidad, west India. Journal of food safety Vol (3). Retrieved from https://d1wqtxts1xzle7.cloudfront.net/31040009/ijfsv3-3-with-coverpage-

v2.pdf?Expires $=1633336834 \&$ Signature $=$ Kd07zoxxIw5Bd9IvZdoYpftbTK6 5y6gPH4JXNrhkR1wEUBk0BC5txn6E4OLY volDfidMQuSH3up8WAixpAu akQlaKD-xI9bRe- 
8cP5CelTblMCG2eHIVpipMT5e0ie 1utozRuY7s0lL0n4mXXIIr59rIsWmiou $\mathrm{XcP} \sim \mathrm{J}-\mathrm{MWO}-\mathrm{f} 6 \mathrm{H} 5 \mathrm{X}-$

y gUS2re3EQJjP94726LJjEJJJFXMwAwIOSKiKpxboerltnwdyMy0QGofreRBH1i46luc0wrc2ZhD0jRD-

TiKrpJ4J1enplX58n9k8gVPrXQfSd1B3YQAtjoM8typdTfathfdAhTkUh4NnH x22XSrEDnKdt7qzO7fe1Hg_\&Key-Pair-Id=APKAJLOHF5GGSLRBV4ZA

Todd, E. C.D., J.D.Greig ,C.A.Bartleson and B.S.Mchaels (2007). Outbreaks where food workers have been implicated in the spread of food borne disease. Part 3 Factors Contributing to outbreaks and description of outbreak categories. J. Food. Retrieved from https://doi.org/10.4315/0362-028X-70.9.2199

Van Kampen ,J.,Gross,R,and Schultinik,W.(1998). The microbiological quality of street foods in Jakarta as Compared to home prepared foods and foods from tourist hotels. Int. J. Food Sci.Nutr.,49,17-26. Retrieved from https://doi.org/10.3109/09637489809086400

WHO (2005). Guidance on Regulatory Assessment of HACCP. WHO/FSF/FOS/05.5.

WHO (2006). Five Keys to Safer Food Manual. Retrieved from http : //www.who. int/food safety/ onsumer/5 keys /en/index.html

WHO (2007). Food safety and food borne illness. Fact sheet No. 237.

WHO (1989). Prevention of food borne disease: Five simple measures could significantly reduce the global incidence of food borne disease. Five keys to safer food WHO Launches new "5 Keys" Strategy in Bangkok, Thailand.

WHO (2010). Five keys to safer food manual 